\title{
Genome Editing for the Production of Natural Products in Escherichia coli
}

DOI:

10.1002/adbi.201800056

\section{Document Version}

Accepted author manuscript

Link to publication record in Manchester Research Explorer

\section{Citation for published version (APA):}

Zebec, Z., \& Scrutton, N. S. (2018). Genome Editing for the Production of Natural Products in Escherichia coli. Advanced Biosystems, 2(11), 1800056. https://doi.org/10.1002/adbi.201800056

\section{Published in:}

Advanced Biosystems

\section{Citing this paper}

Please note that where the full-text provided on Manchester Research Explorer is the Author Accepted Manuscript or Proof version this may differ from the final Published version. If citing, it is advised that you check and use the publisher's definitive version.

\section{General rights}

Copyright and moral rights for the publications made accessible in the Research Explorer are retained by the authors and/or other copyright owners and it is a condition of accessing publications that users recognise and abide by the legal requirements associated with these rights.

\section{Takedown policy}

If you believe that this document breaches copyright please refer to the University of Manchester's Takedown Procedures [http://man.ac.uk/04Y6Bo] or contact uml.scholarlycommunications@manchester.ac.uk providing relevant details, so we can investigate your claim.

\section{OPEN ACCESS}




\section{Genome Editing for the Production of Natural Products in Escherichia coli}

2 Ziga Zebec and Nigel S. Scrutton

3 Manchester Institute of Biotechnology and School of Chemistry, The University of Manchester, Manchester,

$4 \quad$ M1 7DN United Kingdom

5 Correspondence to either nigel.scrutton@manchester.ac.uk or zigazebec@gmail.com

\section{Abstract}

7 Natural products such as secondary metabolites (e.g. plant terpenoids) have been found to be a major source 8 of bioactive compounds. These natural products accumulate as complex mixtures with other related

9 compounds and this chemical complexity adds cost to the downstream recovery and purification of natural products from plant biomass. One aim of synthetic biology and metabolic engineering programmes is to produce such compounds from synthetic gene clusters (SGC) in heterologous hosts and thereby achieve more targeted and affordable production. Both fungi and bacteria are common hosts for metabolic engineering in industry. Fungal hosts include Penicillium chrysogenum, Saccharomyces cerevisiae, Aspergillus niger and the bacterial hosts Escherichia coli, Bacillus subtilis, Corynebacterium glutamicum ${ }^{[1]}$ E. coli is often selected as a host given the ease of its genetic manipulation and the long history ${ }^{[2]}{ }^{[3]}$ of using this organism in laboratorybased bioengineering. ${ }^{[4]}{ }^{[5]}$ The bioengineering of $E$. coli extends also to feedstock pathways to interface and optimise the production of high value compounds from widely available and inexpensive carbon sources. Genome editing is important in these microbial bioengineering programmes and is needed to isolate stable strains and to optimise production. Here we discuss frequently used methods for genome editing in E. coli in relation to the production of natural compounds and chemicals.

\section{Introduction}

Secondary metabolites are high value natural chemicals that are commercially used, for example in the foodflavouring, food-additive, fragrance, pharmaceutical, biochemical and biomedical industries. These natural compounds can be extracted from plant biomass by steam distillation as complex mixtures known as 'Essential Oils'. ${ }^{[6]}$ Many of the natural products, like terpenes and their derivatives (terpenoids), have been tested for potential use as bioactive chemicals and drug candidates for a variety of ailments and many have been shown to have potential benefits in major diseases (e.g. cancer ${ }^{[7]}{ }^{[8]}$ and Alzheimer's ${ }^{[9]}$ ) and to possess antimicrobial activity against multi-drug resistant bacterial pathogens, ${ }^{[10]}$ but most compounds still have not been clinically tested. Most secondary metabolites cannot be extracted from plants as pure compounds and are usually isolated as complex mixtures of natural chemicals. ${ }^{[6]}$ The composition of such natural extracts (e.g. Essential Oils) depends on the geographic location and vegetative stage of plants during harvest. ${ }^{[11]}$ An additional problem is the availability of these compounds since crop yields and access to biomass may fluctuate due to environmental effects or other factors (e.g. disease, land repurposing, political barriers). ${ }^{[12]}$ Many compounds 
are also present in relatively low quantities and intensive purification is required to recover these products

2

3

4

from plant biomass. ${ }^{[6]}$ Alternative routes to sourcing these compounds using synthetic chemistry can be expensive and environmentally costly. ${ }^{[13]}$ These issues have led to an increased emphasis on the production of natural compounds in microbial cells from fermentable and low cost carbon sources. ${ }^{[14]}$ The challenge here is to redirect carbon fluxes from cellular metabolism towards the desired product but is limited by the extent to which natural metabolic pathways - encoded by genetic information contained in the chromosome - can be engineered for this purpose. ${ }^{[15]}$ Production in microbial hosts also presents new downstream processing challenges for recovery of these products from microbial bioreactors. These challenges are often distinct from those associated with purification following production using synthetic chemistry approaches, or from agricultural biomass.

Synthetic biology and metabolic engineering approaches allow one to introduce new 'parts' to the existing genetic frame of a recipient organism enabling extension of existing microbial metabolic frames. These parts are generally organised in synthetic gene clusters (SGC), which comprise the coding sequences for component enzymes and associated regulators (e.g. promoters, ribosome binding sites) required for gene expression. Not only does this enable production of any naturally occurring compound from a known metabolic pathway, but additionally it facilitates production through de novo pathway engineering. ${ }^{[1]}$ A crucial requirement for microbial production is a genetically stable production host, which can maintain its genetic and phenotypic form over time to support optimal production. ${ }^{[16][17]}$ Extracellular DNA in the form of a plasmid is the fastest way to introduce and test a variety of new synthetic pathways in E. coli. ${ }^{[18]}$ However, the continuous use of antibiotics in industrial-scale operations is not acceptable for environmental, cost and stability reasons ${ }^{[19]}$ and plasmids are prone to loose productivity after 20 generations due to unequal plasmid segregation. ${ }^{[16]}$ In this review, we focus on strategies that allow chromosomal manipulations in $E$. coli to i) redirect/manipulate the metabolic frame towards the desired product, and ii) insert genetic information for a heterogeneous pathway (i.e. a novel SGC comprising coding sequences and regulatory parts) to produce a stable production strain. We examine the most recent and prominent cases of genetic frame engineering customized for the production of high value natural products through the insertion of heterologous SGCs. Typically this kind of genetic manipulation requires a set of tools to facilitate genetic manipulations via recombination-mediated genetic engineering or 'recombineering'.

\section{Evolving the 'genetic frame'}

Synthetic biology is a rapidly expanding research field. One aim of this field is to establish routes to stable, pure, natural and environmentally friendly sources of high value natural compounds by production in microbial cell factories. This process starts usually with the selection of a waste carbon source such as cane sugar byproducts $^{[20]}$ or crude glycerol ${ }^{[21]}$ to support fermentative growth through primary metabolic pathways. ${ }^{[22]}$ The classical Darwinian approach of adaptation and selection has historically been an important and powerful tool for natural genome engineering, which is limited by the organisms genomic content. ${ }^{[23]}$ This has been explored from various angles, including the isolation of varieties and strains from the environment with acquired and 
evolved metabolic pathways. For example, a new E. coli strain (strain $\mathrm{ZH}-4$ ) was isolated from bovine rumen

2 and is capable of cellulose utilisation and degradation. ${ }^{[24]}$ As cellulosic wastes are a large, natural and

3 renewable carbon source this shows potential for this metabolic adaption to serve as a genetic framework for

4 further strain modifications. ${ }^{[25]}$ Also, directed evolution in a xylose-based chemostat has enabled the $E$. coli

5 genome to utilize $\mathrm{CO}_{2}$ and to generate glucose. This was achieved using a heterologous Calvin-Benson-

6 Bassham ( $\mathrm{CBB}$ ) cycle, with RuBisCO, phosphoribulokinase (prk), and carbonic anhydrase expressed from a

7 plasmid. ${ }^{[26]}$ Laboratory-based evolution of $E$. coli has been used to introduce mutations in eight different genes

8 (prs, pgi, serA, glmU, crp, ppsR, xylA, and malT) involved in regulating fluxes between the CBB and tricarboxylic

9 acid (TCA) cycles. However, a genetic reconstruction showed that only five of the genes are sufficient to 10 restore the $\mathrm{CO}_{2}$ utilising phenotype of E. coli. ${ }^{[27]}$ Nature can therefore provide a roadmap for how to tap a 11 carbon source that is not only abundant but is also a major industrial waste product. Laboratory evolution in $E$.

12 coli shows that a natural means of genome engineering is important, as it does not require reverse engineering

13 of metabolic pathways to utilise the selected carbon source. ${ }^{[28]}$ Strain evolution using adaptation and selection

14 therefore provides a non-invasive method to engineer the $E$. coli genetic frame to utilise different waste 15 carbon sources and to build up a pool of acetyl-CoA to support metabolic demand. As such, this is an excellent 16 starting point from which to complement this strain by introducing SGCs for the production of complex and 17 valuable natural products and chemicals. 


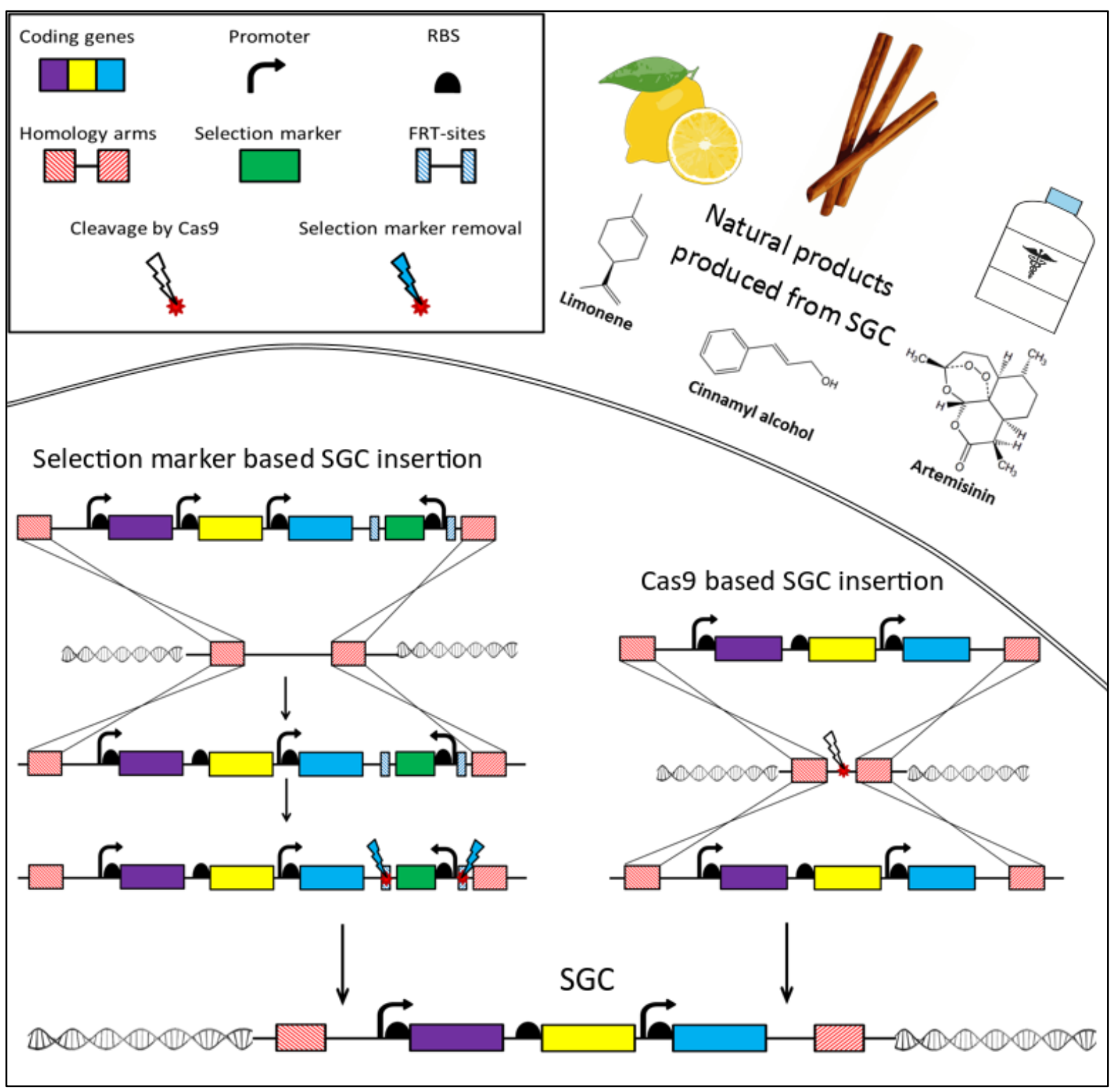

2 Figure 1. Schematic representation of two of the most common strategies used to insert a synthetic gene 3 cluster (SGC) in E. coli with $\lambda$-RED. Selection marker based insertion ( ${ }^{*}$, table 1 ) or Cas 9 based insertion (**, 4 table1). Abbreviations are as followed: FRT = flippase recombination target sites; $R B S=$ ribosome binding site

\section{$5 \quad$ Genome reorganisation and optimisation with the $\lambda$-RED system}

Genome engineering by adaptation and selection is clearly one route to developing $E$. coli strains with a customised genetic frame for use with a carbon feedstock. However, distribution of the incorporated carbon from the acetyl-CoA pool to downstream production pathways requires more targeted fine-tuning of genes or gene circuits involved in those metabolic pathways. ${ }^{[29]}$ Frequently, this is achieved using the $\lambda$-RED system to integrate recombinant and synthetic double stranded (ds) DNA into the $E$. coli chromosome - a method known as 'recombineering' (Figure 1). The $\lambda$-RED system was discovered on the linear DNA of the $\lambda$ bacteriophage and is essential for the virus to transition between lysogenic and the lytic cycles since it enables viral integration into the $E$. coli chromosome. ${ }^{[30]}$ The $\lambda$-RED system comprises three independent subunits (Beta, Exo and Gam) where Gam prevents degradation of linear dsDNA by the RecBCD nuclease, Exo (exonuclease) 
degrades dsDNA in a 5' to $3^{\prime}$ manner to produce single-stranded (ss) DNA templates, and Beta binds to ssDNA

2 to facilitate annealing of homology arms (HA) of a minimum 35nt to repair the chromosome during replication. ${ }^{[31]}$ Curing of the remaining plasmids (e.g. helper or donor plasmid) is usually achieved through the use of a thermo-sensitive origin of replication pSC101. This disables plasmid segregation during replication at $42^{\circ} \mathrm{C}$ and thereby results in plasmid loss. ${ }^{[32]}$ Small changes to the chromosome can be achieved using the $\lambda$-RED system by directing ssDNA (oligos) to the lagging strand of the replication fork in a process called 'oligomediated allelic replacement'. ${ }^{[3][33]}$ This approach has been the cornerstone of modern genome engineering for example in the first multiplexed automated genome engineering (MAGE) platform. ${ }^{[34]}$ The study demonstrated that with sophisticated computational design of 90-mer oligos up to 20 genes can be altered simultaneously with an efficiency of $30 \%$ (in 2 to $2.5 \mathrm{~h}$ ) by introducing mutations of up to 20 nucleotides or deletions of up to 100 nt. $^{[34]}$ Targeted genes located in the 1-deoxy-D-xylulose-5-phosphate pathway were evolved to genetically engineer strains that have up to 5 times higher production levels of the isoprene lycopene compared to the ancestor strain. The natural product lycopene is chemically a tetraterpene assembled from eight isoprene subunits which derive from acetyl-CoA via the mevalonate pathway (MVA) and is most commonly found as a red pigment in fruits like tomatoes. Lycopene is industrially most commonly used as a biological colouring agent. A complementary genome-wide method has also been developed called 'traceable multiplex recombineering' (TRMR) that relies on parallel DNA synthesis and recombineering for molecular barcoding. ${ }^{[35]}$ This method changed the expression profile of $95 \%$ of all genes in E. coli in $24 \mathrm{~h}$ and was utilized for mapping gene-traits of 8,000 distinct mutations in seven different environments. ${ }^{[35]}$ Genome wide stop codon replacement (TGA to TAA) has also been achieved using MAGE ${ }^{[36]}$ and was further optimized by manipulating the replication process. ${ }^{[37]}$ Methyl-directed mismatch repair (MMR) systems have also been used for transient suppression of DNA repair systems, ${ }^{[38]}$ which can be applied to generate sets of genetic frames in E. coli with wide phenotypical diversity. ${ }^{[39]}$ These strategies can be performed in a high throughput (HTP) manner - generating enormous genetic and phenotypic diversity in E. coli - but are limited to maximum insertions of around 20nt.

\section{$\lambda$-RED recombineering for insertion of SGCS}

The $\lambda$-RED system also allows insertion of larger synthetic fragments (e.g. genes and even whole SGCs) but this kind of recombineering requires the use of selection markers flanked by 50nt HA or longer. ${ }^{[40]}$ To remove the selective marker, a site-specific recombinase (termed flippase), that requires 'flippase recombination target sites' (FRT) that flank the antibiotic cassette is needed. An interesting way of using the selection marker is through 'chemically induced chromosomal evolution' (ClChE), which explores the principle of tandem duplication of cassettes. The cassettes comprise a SGC and antibiotic marker (5kb) flanked by $1 \mathrm{~kb}$ homology arms. This needs to be duplicated as a result of adaptation to increased antibiotic concentration, assisted by the $\lambda$-RED system, with the whole process being terminated by the deletion of RecA. ${ }^{[16]}$ The forced multiplication of the SGC allows for rapid evolution of the $E$. coli genetic frame improving the production, for 
example, of lycopene by $60 \%$ over plasmid borne production levels. Moreover, the strain had stable production levels for more than 80 generations in contrast to the plasmid borne production strain, which was stable for less than 20 generation. ${ }^{[16]}$

4 Alternative strategies have allowed insertion of larger SGCs. ${ }^{[41,42]}$ One strategy has relied on the insertion of landing pads (LP) into specific chromosomal sites via 50nt HA flanked by LP of 50nt random sequences. The LP facilitates recombination site, enabling the insertion of an SGC (up to $7 \mathrm{~kb}$ ) into the previously integrated chromosomal site, while I-Scel endonuclease cleaves in the LP to facilitate recombineering. ${ }^{[41]} \mathrm{A}$ different approach is offered by the KIKO (Knock-in/Knock-out) plasmid system, which does not require prior insertion of a LP, but instead requires longer 500nt HA flanked with FRT used to excise the selective marker in an additional step. ${ }^{[42]}$ To date, the largest SGC that has been introduced successfully on the $E$. coli chromosome is $59 \mathrm{~kb}$, using recombinase-assisted genome engineering (RAGE). ${ }^{[17]}$ RAGE requires pre-insertion of a LP that contains a lox flanked selection marker. This is introduced to the chromosome site by the $\lambda$-RED system and is later used to insert the large $59 \mathrm{~kb}$ SGC via a Cre recombination system derived from the P1 phage. ${ }^{[43]}$ The engineered E. coli strain was able to produce $40 \%$ higher titres of ethanol from alginate degradation compared to a comparable plasmid borne system, whilst maintaining the production levels for at least 50 generations. ${ }^{[17]}$ Also, 50kb DNA fragments have been inserted onto the chromosome using only the $\lambda$-RED system. This used seven $7 \mathrm{~kb}$ fragments that had overlapping (minimum 60nt) homology with each other and in this way could be assembled to $50 \mathrm{~kb}$ inserts in a modular-flexible manner. ${ }^{[4]]}$ The $\lambda$-RED system is a versatile and the most applicable tool for fast and economical genome engineering in E. coli. However, it is potentially limited due to unwanted integrations or genome rearrangements that can happen due to high metabolic burden caused by antibiotic use and spontaneous rearrangements attributed to partial similarities of the SGC and regions of the chromosome.

\section{CRISPR/Cas9 mediated recombineering}

The discovery of the bacterial and archaeal viral defence systems called CRISPR (clustered regularly interspaced palindromic repeats) ${ }^{[45]}$ was the basis for developing a new technology for targeted genome engineering, namely CRISPR/Cas9. ${ }^{[46]}$ The technology utilizes the endonuclease activity of Cas9 that is guided by small RNA (crRNA) to its cognate DNA target. DNA cleavage requires not only hybridization between target DNA and crRNA, but also a matching protospacer adjacent motif (PAM e.g. 5'-NGG-3') on the non-targeted DNA strand. ${ }^{[47]}$ The strategy behind the system is to introduce double strand breaks (DSB) with Cas9 in a targeted and programmable fashion. To accomplish the repair of DSB, the $\lambda$-RED system needs a DNA template (synthetic oligonucleotides or plasmid borne dsDNA) with HA that are flanking the DSB in the chromosome but does not require any antibiotic marker integration. ${ }^{[48]}$ The first protocols for CRISPR/Cas9 genome editing in $E$. coli were developed using a dual-RNA system, which comprises the guiding crRNA and an antisense tracrRNA needed for association with Cas9. The whole system is based on three components; the helper plasmid that encodes all the genes of enzymes needed for recombineering (Cas9, $\lambda$-RED system and tracrRNA), a second 
a slightly modified plasmid system up to three target genes can be simultaneously edited. The system is able to integrate up to $4.5 \mathrm{~kb}$ fragments with efficiency of up to $75 \%$, accomplished by using $400 \mathrm{nt} \mathrm{HA}$ and singleguide RNA (sgRNA), which mimics the previously used crRNA-tracrRNA duplex. ${ }^{[49,50]}$ A variation of this strategy has been used to insert a SGC encoding for the pigment $\beta$-carotene, while also altering the genetic frame to increase acetyl-CoA flux availability through the methylerythritol phosphate pathway (MEP) and increasing the production levels of the resulting strain by 3 -fold. ${ }^{[51]} \beta$-carotene pigment is also a member of the terpene family assembled from isoprene units found in most plants. It possesses a red-orange colour and like lycopene is derived from acetyl-CoA via the MVA pathway and is used as a food colouring agent. Further improvements of the editing strategy were achieved using a linear DNA template with a mutated PAM motif on the 5' site of 100nt long HA to prevent sequential cleavage of the targeted DNA by Cas9 after the initial DSB was repaired by the same template. This enabled a markerless chromosomal integration of a $10 \mathrm{~kb}$ SGC with $50 \%$ efficiency ( $14 \mathrm{~kb}$ with $25 \%$ efficiency also reported) and a production for isobutanol at levels similar to the plasmid borne production strain. ${ }^{[52]}$ These methods ${ }^{[42,49]}$ were also recently explored to integrate the melavonate pathway (MVA) and optimize downstream pathways for sucrose utilization (e.g. $\csc A K B$ operon). Extensive efforts were made for a 5-fold higher production of bisabolene in a genome engineered E. coli strain. ${ }^{[53]}$ Bisabolene is a derivative of the MVA pathway which is commonly used as a scent and is a component of many essential oils. ${ }^{[6]}$ This study not only highlights the enormous potential of genome editing, but also points to weaknesses since the $15 \mathrm{~kb}$ SGC had to be split into $5 \mathrm{~kb}$ sub-clusters for successful integration. Additional genome editing of the intrinsic regulators (e.g. promoter) inside the SGC was needed because the chromosomally inserted SGC had different expression levels compared to the SGC encoded on the plasmid. ${ }^{[53]}$ A complementary tool in the CRISPR family is the CRISPR optimized multiple automated genome engineering (CRMAGE), ${ }^{[54]}$ which uses the $\beta$-subunit of the $\lambda$-RED system to introduce 20 nt mutations. Here the genotype of a wild type cell is targeted and degraded by the CRISPR/Cas9 system improving the recombineering efficiency to $97 \%$ and allowing genotype rather than phenotype selection. ${ }^{[54]}$ Recently, this tool was used for genome wide excision of mobile genetic elements in E. coli to engineer a more stable genetic frame. ${ }^{[55]}$ CRISPR systems are at the centre of a rapidly evolving field with seemingly endless potential for developing tools to manipulate nucleic acids on all levels such as $\mathrm{Cpf1}^{[56]}$ or $\mathrm{C} 2 \mathrm{c} 2 .^{[57]}$ These will soon add complementary tools to the existing arsenal of approaches (Table 1) used for genetic engineering in E. coli.

Table 1. Overview of most commonly used methods for recombineering. 


\begin{tabular}{|c|c|c|c|c|c|}
\hline Method & Size inserted & $\begin{array}{c}\text { Components } \\
\text { /mode }\end{array}$ & $\begin{array}{l}\text { Homology } \\
\text { arms }\end{array}$ & $\begin{array}{c}\text { Product } \\
\text { /increase } \\
\end{array}$ & References \\
\hline $\begin{array}{c}\text { laboratory strain } \\
\text { evolution }\end{array}$ & $\begin{array}{c}\text { Not } \\
\text { specified }\end{array}$ & $\begin{array}{l}\text { one plasmid } \\
\text { /chemostat cultivation }\end{array}$ & Not utilized & $\mathrm{CO}_{2}$ utilization & [26] \\
\hline MAGE & $20 n t$ & $\begin{array}{c}\lambda-\text { RED } \\
/ \text { HTP } \\
\end{array}$ & $35 n t$ & $\begin{array}{l}\text { Lycopene /4- } \\
\text { fold }^{[35]}\end{array}$ & $\begin{array}{c}\text { [34] }]^{36]}, \\
{[39]}\end{array}$ \\
\hline CIChE & $5 \mathrm{~kb}$ & $\begin{array}{l}\lambda \text {-RED } \\
/ \text { HTP }\end{array}$ & $1 \mathrm{~kb}$ & $\begin{array}{c}\text { Lycopene } \\
/ 60 \%\end{array}$ & {$[16]$} \\
\hline RAGE & $59 \mathrm{~kb}$ & $\begin{array}{c}\lambda \text {-RED \& } \\
\text { Cre-recombinase } \\
\text { /HTP }\end{array}$ & lox site & $\begin{array}{l}\text { Ethanol from } \\
\text { alginate } \\
/ 40 \%\end{array}$ & {$[17]$} \\
\hline $\begin{array}{c}\lambda \text {-RED high } \\
\text { molecular weight } \\
{\left[{ }^{*}\right]}\end{array}$ & $\begin{array}{c}7 \times 7 \mathrm{~kb}= \\
50 \mathrm{~kb}\end{array}$ & $\begin{array}{c}\lambda \text {-RED } \\
/ \text { Single cell }\end{array}$ & $\begin{array}{c}\text { minimum } \\
60 \mathrm{nt}\end{array}$ & Lactose utilization & [44] \\
\hline $\begin{array}{c}\mathrm{KIKO} \\
{[*]}\end{array}$ & $5.4 \mathrm{~kb}$ & $\begin{array}{c}\lambda \text {-RED \& FRT } \\
\text { /Single cell }\end{array}$ & 500nt & Not specified & {$[42]$} \\
\hline $\begin{array}{c}\text { Landing pad } \\
{\left[{ }^{*}\right]} \\
\end{array}$ & $7 \mathrm{~kb}$ & $\begin{array}{c}\lambda \text {-RED \& I-Scel \& FRT } \\
\text { /Single cell }\end{array}$ & 50nt & Not specified & [41] \\
\hline $\begin{array}{c}\text { CRISPR/Cas9 } \\
{[* *]}\end{array}$ & $4.5 \mathrm{~kb}$ & $\begin{array}{c}\lambda \text {-RED \& Cas9 } \\
\text { /Single cell }\end{array}$ & 400nt & $\begin{array}{l}\beta \text {-carotene } \\
/ 2.8 \text {-fold }^{[52]}\end{array}$ & $\begin{array}{l}{[49]} \\
{[51]}\end{array}$ \\
\hline $\begin{array}{c}\text { CRISPR/Cas9 } \\
\text { PAM-mutation } \\
{[* *]}\end{array}$ & $10 \mathrm{~kb}$ & $\begin{array}{c}\lambda \text {-RED \& Cas9 } \\
\text { /Single cell }\end{array}$ & 100nt & $\begin{array}{l}\text { Isobutanol } \\
\text { /equal level }\end{array}$ & {$[52]$} \\
\hline $\begin{array}{l}\text { CRISPR/Cas9 \& } \\
\text { KIKO }\end{array}$ & $\begin{array}{c}3 \times 5 \mathrm{~kb}= \\
15 \mathrm{~kb}\end{array}$ & $\begin{array}{c}\lambda \text {-RED \& Cas9 } \\
\text { /Single cell }\end{array}$ & $500 n t$ & $\begin{array}{l}\text { Bisabolene } \\
\text { /5-fold }\end{array}$ & {$[53]$} \\
\hline CRMAGE & $20 n t$ & $\begin{array}{c}\lambda \text {-RED } \\
/ \text { HTP }\end{array}$ & $35 n t$ & Not specified & $\begin{array}{l}{[54]} \\
{[55]}\end{array}$ \\
\hline
\end{tabular}

*Schematically represented in Figure $1 ; * *$ Schematically represented in Figure 1

\section{Conclusions and outlook}

5 Genome engineering can be used to generate $E$. coli strains with a genetic frame that harbours a SGC for the production of high value secondary metabolites. Recent work has demonstrated an ability to engineer genetic frames that utilize abundant and inexpensive carbon sources to produce acetyl-CoA using laboratory strain evolution, MAGE, TRMR or CRMAGE platforms. The $\lambda$-RED system is the most routinely used method to introduce SGCS onto the E. coli chromosome. However, with this system larger SGCs (up to 8kb) require coinsertion of a selection marker. The use of antibiotic resistance cassettes can be avoided by using a CRISPR/Cas9 system, which introduces a targeted DSB in the chromosome and establishes a selective pressure for E. coli to repair the DSB. More specialised methods - for example RAGE - can be used to insert very large fragments (up to $50 \mathrm{~Kb}$ ). Chemically induced chromosomal evolution (CIChE) can also be used to increase the chromosomal SGC copy number to achieve higher production levels. A variety of tools for genetic engineering are therefore available, but these still require exquisite laboratory handling skills for sub-cloning and culturing, detailed investigation of existing tool sets and method optimization. No doubt the future will usher in an explosion in the number of newly identified SGCs ${ }^{[58]}$ as well as new tools for genome engineering. ${ }^{[59]}$ All this 
will be timely if we are to reproduce and diversify the natural products provided by nature and manufacture new medicines for societal benefit. The relative ease by which genome editing can now be achieved in $E$. coli should lead to rapid isolation of stable strains for the production of bioactive natural products as well as fine and speciality chemicals, platform chemicals, therapeutics and components for new synthetic biological materials.

\section{Acknowledgements}

Work in the authors laboratory is funded by the UK Biotechnology and Biological Sciences Research Council (BBSRC BB/L027593/1; BB/M017702/1; BB/M000354/1). This is a contribution from the BBSRC/EPSRC Manchester Synthetic Biology Research Centre SYNBIOCHEM.

\section{References}

[1] J. Nielsen, J. D. Keasling, Cell 2016, 164, 1185.

[2] R. Simon, U. Priefer, A. Pühler, Nature biotechnology 1983, 1, 784.

[3] D. Yu, H. M. Ellis, E. C. Lee, N. A. Jenkins, N. G. Copeland, D. L. Court, Proc. Natl. Acad. Sci. USA 2000, 97, 5978.

[4] A. Schirmer, M. A. Rude, X. Li, E. Popova, S. B. Del Cardayre, Science 2010, 329, 559.

[5] E. J. Steen, Y. Kang, G. Bokinsky, Z. Hu, A. Schirmer, A. McClure, S. B. Del Cardayre, J. D. Keasling, Nature 2010, 463, 559.

[6] K. H. C. Baser, G. Buchbauer, Handbook of essential oils: science, technology, and applications, CRC Press, 2015.

[7] V. Bogdanovic, J. Mrdjanovic, I. Borisev, J. Altern. Complement. Med. 2017, 23, 831.

[8] S. Slezakova, J. Ruda-Kucerova, Anticancer Res. 2017, 37, 5995.

[9] M. F. Zafeer, F. Firdaus, F. Ahmad, R. Ullah, E. Anis, M. Waseem, A. Ali, M. M. Hossain, Int. J. Biol. Macromol. 2018, 109, 1029.

[10] R. Subramani, M. Narayanasamy, K. D. Feussner, 3 Biotech 2017, 7, 172.

[11] G. Dugo, I. S. d'Alcontres, A. Cotroneo, P. Dugo, Journal of Essential Oil Research 1992, 4, 589.

[12] A. J. Challinor, J. Watson, D. Lobell, S. Howden, D. Smith, N. Chhetri, Nature Climate Change 2014, 4, 287.

[13] K. Geoghegan, P. Evans, Tetrahedron Lett. 2014, 55, 1431.

[14] C. W. Marshall, E. V. LaBelle, H. D. May, Curr. Opin. Biotechnol. 2013, 24, 391.

[15] A. M. Feist, B. Ø. Palsson, Nat. Biotechnol. 2008, 26, 659.

[16] K. E. Tyo, P. K. Ajikumar, G. Stephanopoulos, Nat. Biotechnol. 2009, 27, 760.

[17] C. N. Santos, D. D. Regitsky, Y. Yoshikuni, Nat. Commun. 2013, 4, 2503.

[18] N. G. Leferink, A. J. Jervis, Z. Zebec, H. S. Toogood, S. Hay, E. Takano, N. S. Scrutton, ChemistrySelect 2016, 1, 1893.

[19] G. Le Page, L. Gunnarsson, J. Snape, C. R. Tyler, Environ. Int. 2017.

[20] C. C. Geddes, M. T. Mullinnix, I. U. Nieves, J. J. Peterson, R. W. Hoffman, S. W. York, L. P. Yomano, E. N. Miller, K. T. Shanmugam, L. O. Ingram, Bioresour. Technol. 2011, 102, 2702.

[21] M. Saini, Z. W. Wang, C. J. Chiang, Y. P. Chao, Biotechnol. Biofuels 2017, 10, 173.

[22] K. Martinez-Gomez, N. Flores, H. M. Castaneda, G. Martinez-Batallar, G. Hernandez-Chavez, O. T. Ramirez, G. Gosset, S. Encarnacion, F. Bolivar, Microb. Cell Fact. 2012, 11, 46.

[23] M. Dragosits, D. Mattanovich, Microb. Cell Fact. 2013, 12, 64.

[24] J. Pang, Z.-Y. Liu, M. Hao, Y.-F. Zhang, Q.-S. Qi, Biotechnol. Biofuels 2017, 10, 165. 
[25] A. Arevalo-Gallegos, Z. Ahmad, M. Asgher, R. Parra-Saldivar, H. M. N. Iqbal, Int. J. Biol. Macromol. 2017, 99, 308.

[26] N. Antonovsky, S. Gleizer, E. Noor, Y. Zohar, E. Herz, U. Barenholz, L. Zelcbuch, S. Amram, A. Wides, N. Tepper, D. Davidi, Y. Bar-On, T. Bareia, D. G. Wernick, I. Shani, S. Malitsky, G. Jona, A. BarEven, R. Milo, Cell 2016, 166, 115.

[27] E. Herz, N. Antonovsky, Y. Bar-On, D. Davidi, S. Gleizer, N. Prywes, L. Noda-Garcia, K. Lyn Frisch, Y. Zohar, D. G. Wernick, A. Savidor, U. Barenholz, R. Milo, Nat. Commun. 2017, 8, 1705.

[28] C. P. Long, J. E. Gonzalez, A. M. Feist, B. O. Palsson, M. R. Antoniewicz, Metab. Eng. 2017, 44, 100; C. P. Long, J. E. Gonzalez, A. M. Feist, B. O. Palsson, M. R. Antoniewicz, Proc. Natl. Acad. Sci. USA 2018, 115, 222.

[29] A. Rodriguez, J. A. Martinez, N. Flores, A. Escalante, G. Gosset, F. Bolivar, Microb. Cell Fact. 2014, 13, 126.

[30] C. M. Radding, J. Mol. Biol. 1970, 52, 491.

[31] J. A. Mosberg, M. J. Lajoie, G. M. Church, Genetics 2010, 186, 791.

[32] M. G. Thompson, N. Sedaghatian, J. F. Barajas, M. Wehrs, C. B. Bailey, N. Kaplan, N. J. Hillson, A. Mukhopadhyay, J. D. Keasling, Sci. Rep. 2018, 8, 1590.

[33] H. M. Ellis, D. Yu, T. DiTizio, D. L. Court, Proc. Natl. Acad. Sci. USA 2001, 98, 6742.

[34] H. H. Wang, F. J. Isaacs, P. A. Carr, Z. Z. Sun, G. Xu, C. R. Forest, G. M. Church, Nature 2009, $460,894$.

[35] J. R. Warner, P. J. Reeder, A. Karimpour-Fard, L. B. A. Woodruff, R. T. Gill, Nat. Biotechnol. 2010, 28, 856.

[36] F. J. Isaacs, P. A. Carr, H. H. Wang, M. J. Lajoie, B. Sterling, L. Kraal, A. C. Tolonen, T. A. Gianoulis, D. B. Goodman, N. B. Reppas, C. J. Emig, D. Bang, S. J. Hwang, M. C. Jewett, J. M. Jacobson, G. M. Church, Science 2011, 333, 348.

[37] M. J. Lajoie, C. Gregg, J. Mosberg, G. Washington, G. Church, Nucleic Acids Res. 2012, 40, e170.

[38] A. Nyerges, B. Csorgo, I. Nagy, B. Balint, P. Bihari, V. Lazar, G. Apjok, K. Umenhoffer, B.

Bogos, G. Posfai, C. Pal, Proc. Natl. Acad. Sci. USA 2016, 113, 2502.

[39] G. Kuznetsov, D. B. Goodman, G. T. Filsinger, M. Landon, N. Rohland, J. Aach, M. J. Lajoie, G. M. Church, Genome Biol. 2017, 18, 100.

[40] S. K. Sharan, L. C. Thomason, S. G. Kuznetsov, D. L. Court, Nat. Protoc. 2009, 4, 206.

[41] T. E. Kuhlman, E. C. Cox, Nucleic Acids Res. 2010, 38, e92.

[42] S. Sabri, J. A. Steen, M. Bongers, L. K. Nielsen, C. E. Vickers, Microb. Cell Fact. 2013, 12, 60.

[43] G. D. van Duyne, in Mobile DNA III, American Society of Microbiology, 2015, 119.

[44] M. Juhas, J. W. Ajioka, Microb. Cell Fact. 2016, 15, 172.

[45] E. V. Koonin, K. S. Makarova, Y. I. Wolf, Annu. Rev. Microbiol. 2017, 71, 233.

[46] M. Jinek, K. Chylinski, I. Fonfara, M. Hauer, J. A. Doudna, E. Charpentier, Science 2012, 337,

816.

[47] C. Anders, O. Niewoehner, A. Duerst, M. Jinek, Nature 2014, 513, 569.

[48] W. Jiang, D. Bikard, D. Cox, F. Zhang, L. A. Marraffini, Nat. Biotechnol. 2013, 31, 233.

[49] Y. Jiang, B. Chen, C. Duan, B. Sun, J. Yang, S. Yang, Appl. Environ. Microbiol. 2015, 81, 2506.

[50] M. E. Pyne, M. Moo-Young, D. A. Chung, C. P. Chou, Appl. Environ. Microbiol. 2015, 81, 5103.

[51] Y. Li, Z. Lin, C. Huang, Y. Zhang, Z. Wang, Y. J. Tang, T. Chen, X. Zhao, Metab. Eng. 2015, 31, 13.

[52] M. C. Bassalo, A. D. Garst, A. L. Halweg-Edwards, W. C. Grau, D. W. Domaille, V. K. Mutalik, A. P. Arkin, R. T. Gill, ACS Synth. Biol. 2016, 5, 561.

[53] J. Alonso-Gutierrez, D. Koma, Q. Hu, Y. Yang, L. J. G. Chan, C. J. Petzold, P. D. Adams, C. E. Vickers, L. K. Nielsen, J. D. Keasling, T. S. Lee, Biotechnol. Bioeng. 2017.

[54] C. Ronda, L. E. Pedersen, M. O. Sommer, A. T. Nielsen, Sci. Rep. 2016, 6, 19452.

[55] K. Umenhoffer, G. Draskovits, A. Nyerges, I. Karcagi, B. Bogos, E. Timar, B. Csorgo, R. Herczeg, I. Nagy, T. Feher, C. Pal, G. Posfai, ACS Synth. Biol. 2017, 6, 1471. 
1 [56] B. Zetsche, M. Heidenreich, P. Mohanraju, I. Fedorova, J. Kneppers, E. M. DeGennaro, N.

2 Winblad, S. R. Choudhury, O. O. Abudayyeh, J. S. Gootenberg, W. Y. Wu, D. A. Scott, K. Severinov, J. 3 van der Oost, F. Zhang, Nat. Biotechnol. 2016, 35, 31.

4 [57] O. O. Abudayyeh, J. S. Gootenberg, S. Konermann, J. Joung, I. M. Slaymaker, D. B. T. Cox, S. 5 Shmakov, K. S. Makarova, E. Semenova, L. Minakhin, K. Severinov, A. Regev, E. S. Lander, E. V.

6 Koonin, F. Zhang, Science 2016, 353.

7 [58] S. Mukherjee, R. Seshadri, N. J. Varghese, E. A. Eloe-Fadrosh, J. P. Meier-Kolthoff, M. Goker, 8 R. C. Coates, M. Hadjithomas, G. A. Pavlopoulos, D. Paez-Espino, Y. Yoshikuni, A. Visel, W. B.

9 Whitman, G. M. Garrity, J. A. Eisen, P. Hugenholtz, A. Pati, N. N. Ivanova, T. Woyke, H. P. Klenk, N. C. 10 Kyrpides, Nat. Biotechnol. 2017, 35, 676.

11 [59] S. Doron, S. Melamed, G. Ofir, A. Leavitt, A. Lopatina, M. Keren, G. Amitai, R. Sorek, Science 2018. 